\title{
Correction to: Integrating Regional Management Needs into a Mid-Atlantic Shorelines Research Project
}

\author{
Elizabeth Turner ${ }^{1} \cdot$ Thomas Jordan $^{2}$
}

Published online: 7 January 2019

(C) The Author(s) 2019

\section{Correction to: Estuaries and Coasts (2018) 41 (Suppl 1): S223-S234 \\ https://doi.org/10.1007/s12237-017-0261-y}

The article Integrating Regional Management Needs into a Mid-Atlantic Shorelines Research Project, written by Elizabeth Turner and Thomas Jordan, was originally published electronically on the publisher's internet portal (currently SpringerLink) on 12 June 2017 without open access.

With the author(s)' decision to opt for Open Choice the copyright of the article changed January 2019 to (C) The Author(s) 2019 and the article is forthwith distributed under the terms of the Creative Commons Attribution 4.0 International License (http://creativecommons.org/licenses/by/4.0/), which permits use, duplication, adaptation, distribution and reproduction in any medium or format, as long as you give appropriate credit to the original author(s) and the source, provide a link to the Creative Commons license and indicate if changes were made.

The original article has been corrected.

Open Access This article is distributed under the terms of the Creative Commons Attribution 4.0 International License (http:// creativecommons.org/licenses/by/4.0/), which permits use, duplication, adaptation, distribution and reproduction in any medium or format, as long as you give appropriate credit to the original author(s) and the source, provide a link to the Creative Commons license and indicate if changes were made.

The online version of the original article can be found at https://doi.org/ 10.1007/s12237-017-0261-y

Elizabeth Turner

Elizabeth.turner@noaa.gov

Thomas Jordan

jordanth@si.edu

1 National Oceanic and Atmospheric Administration, National Centers for Coastal Ocean Science, Room 146 Gregg Hall, 35 Colovos Road, Durham, NH 03824, USA

2 Smithsonian Environmental Research Center, 647 Contees Wharf Road, Edgewater, MD 21037, USA 